\title{
Stocks and losses of soil organic carbon from Chinese vegetated coastal habitats
}

\author{
Chuancheng $\mathrm{Fu}^{1,2}$ (D) | Yuan $\mathrm{Li}^{2}$ | Lin Zeng ${ }^{3}$ | Haibo Zhang ${ }^{4}$ Ｃ Chen $\mathrm{Tu}^{2}$ | Qian Zhou ${ }^{2,5}$ \\ Kuanxu Xiong ${ }^{2}$ | Jiaping Wu ${ }^{6}$ | Carlos M. Duarte ${ }^{7}$ | Peter Christie ${ }^{1}$ (D) | Yongming Luo ${ }^{1,2,5}$ (D)
}

${ }^{1}$ CAS Key Laboratory of Soil Environment and Pollution Remediation, Institute of Soil Science, Chinese Academy of Sciences, Nanjing, China

${ }^{2}$ CAS Key Laboratory of Coastal Environmental Processes and Ecological Remediation, Yantai Institute of Coastal Zone Research, Chinese Academy of Sciences, Yantai, China

${ }^{3}$ School of Resources and Environmental Engineering, Ludong University, Yantai, China ${ }^{4}$ Key Laboratory of Soil Contamination Bioremediation of Zhejiang Province, School of Environmental and Resource Sciences, Zhejiang A\&F University, Hangzhou, China

${ }^{5}$ University of Chinese Academy of Sciences, Beijing, China

${ }^{6}$ Ocean College, Zhejiang University, Zhoushan, China

${ }^{7}$ Red Sea Research Center (RSRC) and Computational Bioscience Research Center (CBRC), Biological and Environmental Sciences \& Engineering Division (BESE), King Abdullah University of Science and Technology (KAUST), Thuwal, Saudi Arabia

\section{Correspondence}

Yongming Luo, CAS Key Laboratory of Soil Environment and Pollution Remediation, Institute of Soil Science, Chinese Academy of Sciences, Nanjing, China.

Email:ymluo@issas.ac.cn

\section{Funding information}

National Natural Science Foundation of China, Grant/Award Number: 41991330 and 41701263; Key Research Projects of Frontier Science, Chinese Academy of Sciences, Grant/Award Number: QYZDJSSW-DQC015

\begin{abstract}
Global vegetated coastal habitats (VCHs) represent a large sink for organic carbon (OC) stored within their soils. The regional patterns and causes of spatial variation, however, remain uncertain. The sparsity and regional bias of studies on soil OC stocks from Chinese VCHs have limited the reliable estimation of their capacity as regional and global OC sinks. Here, we use field and published data from 262 sampled soil cores and 181 surface soils to report estimates of soil OC stocks, burial rates and losses of VCHs in China. We find that Chinese mangrove, salt marsh and seagrass habitats have relatively low $O C$ stocks, storing $6.3 \pm 0.6,7.5 \pm 0.6$, and $1.6 \pm 0.6 \mathrm{Tg}$ $C( \pm 95 \%$ confidence interval) in the top meter of the soil profile with burial rates of $44 \pm 17,159 \pm 57$, and $6 \pm 45 \mathrm{Gg}$ C/year, respectively. The variability in the soil OC stocks is linked to biogeographic factors but is mostly impacted by sedimentary processes and anthropic activities. All habitats have experienced significant losses, resulting in estimated emissions of 94.2-395.4 $\mathrm{Tg} \mathrm{CO}_{2} \mathrm{e}$ (carbon dioxide equivalent) over the past 70 years. Reversing this trend through conservation and restoration measures has, therefore, great potential in contributing to the mitigation of climate change while providing additional benefits. This assessment, on a national scale from highly sedimentary environments under intensive anthropogenic pressures, provides important insights into blue carbon sink mechanism and sequestration capacities, thus contributing to the synchronous progression of global blue carbon management.
\end{abstract}

\section{KEYWORDS}

blue carbon, carbon burial, carbon loss, carbon stock, climate change, sequestration potential, soil organic carbon

\section{1 | INTRODUCTION}

Vegetated coastal habitats (VCHs; mangroves, salt marshes, and seagrass meadows) occupy only $<0.3 \%$ of the ocean surface

See also the Commentary on this article by Glatzel and Herndl, 27, 3-4. but, with an estimated organic carbon (OC) burial capacity of $0.08-0.22 \mathrm{Pg} \mathrm{C} /$ year globally, and contribute $46.9 \%$ of the total amount of carbon buried in marine sediments (Duarte et al., 2013; Mcleod et al., 2011; Serrano et al., 2019). Complex root structures, high sedimentation rates, and anoxic soils in $\mathrm{VCH}$ s have resulted in the accumulation of large amounts of 
soil OC stock over millennia, making these ecosystems globally significant OC sinks (Atwood et al., 2017; Howard et al., 2014). Present global datasets indicate the soil OC stocks of mangroves, salt marshes, and seagrasses at 2.6-3.0, 0.4-6.5, 4.2$8.4 \mathrm{Pg}$ respectively, with large variability in OC stocks from local through to global scales (Atwood et al., 2017; Duarte et al., 2013; Fourqurean et al., 2012; Hamilton \& Friess, 2018). Indeed, the quantities and rates of $\mathrm{OC}$ that $\mathrm{VCHs}$ can bury in underlying soils vary across climatic zones, geomorphic settings (e.g., estuarine, marine), species composition, and anthropic disturbance (Atwood et al., 2017; Hayes et al., 2017; Osland et al., 2018; Rovai et al., 2018). However, reliable data from a sufficient number of representative sampling sites are still lacking for many regions including China, due to the imbalance of research effort across regions and possible bias toward carbon-rich sites (AriasOrtiz, Serrano, et al., 2018; Atwood et al., 2017; Fourqurean et al., 2012; Murdiyarso et al., 2015). Nationwide or global extrapolation based on limited and possibly biased data adds substantial uncertainty to estimates of $O C$ stocks and accumulation rates in VCHs (Miyajima et al., 2015). Thus, filling geographic gaps in soil OC stocks and accumulation rates as well as understanding their physical and biological drivers are required to support OC management regionally and globally.

Mangrove, salt marsh, and seagrass habitats are under high levels of anthropogenic threat (for example, land-use change, drainage, pollution) with coastal development, leading to global historical rates of decline of $1 \%-2 \%, 0.7 \%-3 \%$ and $0.9 \%$ year $^{-1}$, respectively (Duarte et al., 2013; Waycott et al., 2009). Degradation and removal of $\mathrm{VCH}$ have the potential to disturb soil OC down to depths below 1 meter, leading to remineralization to $\mathrm{CO}_{2}$ (Arias-Ortiz, Serrano, et al., 2018; Atwood et al., 2017; Carnell et al., 2018). As a result, the remineralization of soil OC in disturbed VCHs may add significantly to the component of anthropogenic greenhouse gas (GHG) emissions designated as "land-use change," which is still unaccounted for in global OC inventories (Atwood et al., 2017). An emerging body of literature estimates $\mathrm{CO}_{2}$ emissions at global or regional scales (Atwood et al., 2017; Carnell et al., 2018; Hamilton \& Friess, 2018; Kauffman et al., 2014), with a paucity of national $\mathrm{CO}_{2}$ emissions from $\mathrm{VCH}$ disturbance at a time when nations are encouraged to include nature-based solutions such as the conservation and restoration of VCHs. Countryspecific estimates such as those developed in Australia (Serrano et al., 2019) represent a contributory step in the inclusion of $\mathrm{VCHs}$ in Nationally Determined Contributions (NDCs) for climate change mitigation and adaptation.

China is expected to have great potential to develop blue carbon strategies for climate change mitigation and adaption because of its long coastline and large sediment supply to support VCHs (Wang et al., 2016; Zhang et al., 2015). Chinese VCHs span from the tropics to temperate zones (Zhou et al., 2016), with high richness in mangrove, salt marsh, and seagrass species (Liao \& Zhang, 2014; Mu et al., 2015; Zheng et al., 2013). However, large amounts of $\mathrm{VCH}$ s have been destroyed during the rapid economic development of China during the past 70 years, and this has ultimately reduced their extents and diversities (Zhou et al., 2016). Although several studies have estimated soil OC stocks in Chinese VCHs (Jiao et al., 2018; Liu et al., 2014; Meng et al., 2019), reliable estimates of soil OC stocks and losses are still unavailable for much of this large and dynamic region. China is the largest $\mathrm{CO}_{2}$ emitter in the world and is a nation with a large population at risk from sea-level rise (SLR) and cyclones (Neumann et al., 2015), and would benefit from blue carbon strategies for climate change mitigation and adaptation, which require the quantification of $\mathrm{OC}$ stocks and losses of VCHs. A field-based estimate of the soil OC stock of all the VCHs in China is therefore urgently needed to fulfill information needs that support coastal management and policy decisions.

The specific objectives of the current study were to (a) estimate soil OC stocks and accumulation rates in the Chinese VCHs; (b) assess soil OC losses in the $\mathrm{VCH}$ during the rapid development of China; and (c) explore biogeographic and anthropic drivers of the distribution and dynamics of soil OC stocks in the Chinese VCHs.

\section{2 | MATERIALS AND METHODS}

\section{1 | Soil sampling and analysis}

Based on the distribution, species composition, and structure of Chinese mangroves, salt marshes, and seagrasses, we determined sampling sites representing these ecosystems across the country according to the representativeness of the vegetation types and the sampling method outlined by the Blue Carbon Initiative (Howard et al., 2014). The fieldwork was conducted between March and October, 2017. About 55 soil cores (15 mangrove soil cores, 27 salt marsh soil cores, and 13 seagrass soil cores, Figure 1a; Table S1) and 181 surface soils (50 mangrove soils, 93 salt marsh soils, and 38 seagrass soils, Figure $1 \mathrm{~b}$ ) were collected along the coastline of China (not including Hong Kong, Macao, and Taiwan because of access difficulties in these regions). Soil cores were collected at $30 \%$ of the topsoil sampling sites where the $\mathrm{VCH}$ s were large in area and with relatively stable depositional environments. Soil cores were taken using polycarbonate (PC) corers (130 or $170 \mathrm{~cm}$ long, $10 \mathrm{~cm}$ internal diameter) that were hammered into the substrate at low tide. Compression of the soils during coring was alleviated by distributing the spatial discordances proportionally between the expected and the observed soil column layers (Arias-Ortiz, Serrano, et al., 2018). The cores were sealed, packaged in black plastic film, and stored in a cold room at $4^{\circ} \mathrm{C}$. In the laboratory, the corers were split lengthwise and the soils inside were sliced at 2 or $5 \mathrm{~cm}$ thick intervals. A radial clustered plot design with five subsamples $(0-20 \mathrm{~cm})$ was adopted in the fieldwork (Howard et al., 2014). Plant tissues (leaves, branches, and rhizomes) without (or with fewer) epiphytes were sampled from five randomly selected $\mathrm{VCH}$ plants 


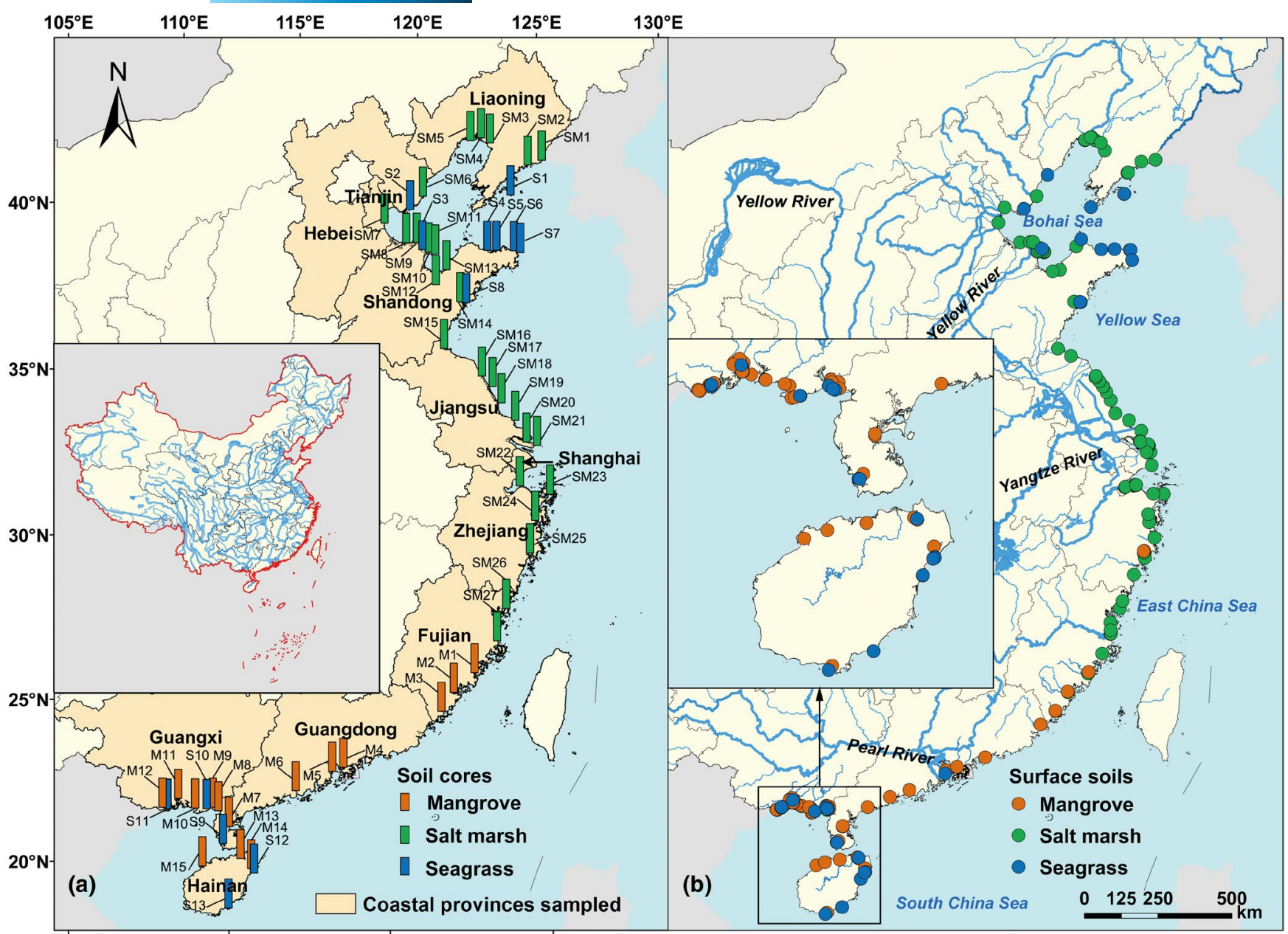

FIGURE 1 Spatial distribution of (a) soil cores and (b) surface soils in the Chinese vegetated coastal habitats sampled

and combined to give one composite sample at some of the soil sites. All plant tissue samples were washed with deionized water and oven-dried at $60^{\circ} \mathrm{C}$ to constant weight. Epiphytes, if present, were removed using an ultrasonic bath or a scalpel blade (Kennedy et al., 2010).

Dry bulk density (DBD) was determined as a simple dry weight-to-volume ratio. Ten $\mathrm{cm}^{3}$ of the soil were taken from each $5 \mathrm{~cm}$ thick subsample using a syringe and dispensed into a preweighed container and oven dried to constant weight at $60^{\circ} \mathrm{C}$ (Howard et al., 2014). Samples were prepared for OC analysis by freezing the surface and horizon soils at $-20^{\circ} \mathrm{C}$ and later freeze-drying, grinding, and sieving to $<0.145 \mathrm{~mm}$ to obtain the fine earth. The soil OC content analysis was conducted using $1 \mathrm{M} \mathrm{HCl}$ to remove inorganic carbon after weighing and subsequently rinsing with deionized water to wash and neutralize. The residue samples were then freeze-dried for $O C$ and $\delta^{13} C$ analysis using a Vario MACRO cube elemental analyzer (Elementar Analysensysteme) and a Thermo MAT253 mass spectrometer (Thermo Fisher Scientific; continuous flow mode), respectively. The measured isotope ratios were expressed using conventional $\delta$ notation $\left(\delta^{13} \mathrm{C}\right.$, in permil) with Peedee Belemnite (PDB) as the reference material. Replicate samples and standards accounted for
$10 \%$ with measurement errors of $\pm 1 \%$ and $\pm 0.1 \%$ for OC content and $\delta^{13} \mathrm{C}$, respectively. The soil labile organic carbon (LOC) content which is oxidizable by $\mathrm{KMnO}_{4}$ was determined following the description of Blair et al. (1995). In brief, finely ground soil samples were allowed to react with $333 \mathrm{mmol} / \mathrm{L} \mathrm{KMnO}_{4}$ in centrifuge tubes and shaken at $60 \mathrm{rev} / \mathrm{min}$ for $1 \mathrm{hr}$. The suspensions were then centrifuged at 2,000 rev/min for $5 \mathrm{~min}$ and the supernatants were diluted and determined spectrophotometrically at $565 \mathrm{~nm}$. The amount of oxidized carbon was estimated as the change in the concentration of $\mathrm{KMnO}_{4}$, and the $\mathrm{LOC}$ was expressed as mg C/g soil.

Four mangrove soil cores (M4, M6, M7, and M9), six salt marsh soil cores (SM2, SM4, SM17, SM20, SM22, and SM25), and six seagrass soil cores (S2, S3, S6, S9, S10, and S13; sliced at $2 \mathrm{~cm}$ thick intervals) were analyzed for ${ }^{210} \mathrm{~Pb}$ concentrations to determine recent (last century) sediment accumulation rates. Sample aliquots $(\sim 5 \mathrm{~g})$ in $2 \mathrm{~cm}$ slices were analyzed for total ${ }^{210} \mathrm{~Pb}$ and ${ }^{226} \mathrm{Ra}$ using a Germanium ray spectrometer (Ortec Instruments). The total ${ }^{210} \mathrm{~Pb}$ activities at a gamma-ray energy of $46.5 \mathrm{keV}$ were measured. Assuming that the radioactive equilibrium of the uranium decay series had been established in the sediments, the ${ }^{214} \mathrm{~Pb}$ activities (351.9 keV) were subtracted from the ${ }^{210} \mathrm{~Pb}$ activities to calculate the excess ${ }^{210} \mathrm{~Pb}$ 
activities. The measurement precision was between ca. $\pm 5 \%$ and $\pm 10 \%$ at the $95 \%$ confidence level.

\subsection{Soil OC stock calculation, extrapolation, and synthesis of published literature}

Soil organic carbon (SOC) stocks in VCHs were quantified by multiplying SOC and DBD data by soil depth increment $(5 \mathrm{~cm})$ of the sampled soil cores. We took a conservative approach by focusing only on the top meter of the soils since these pools are the most susceptible to land-use change. We also compiled published data on Chinese VCH soil OC stocks (criteria: published after 2007; core depth $>50 \mathrm{~cm}$ ) from Google Scholar, Web of Science, and CNKI after confirming their validity (Table S2). We first calculated and modeled the depth variability of SOC and DBD by soil depth increment $(<5 \mathrm{~cm})$ using the sampled cores and long cores from the literature grouped by plant species to extrapolate SOC and DBD of the short cores (i.e., core length $<1 \mathrm{~m}$ ) to $1 \mathrm{~m}$ (Table S3). We also extrapolated SOC and DBD of the surface soils to $1 \mathrm{~m}$ to acquire more core data, especially in regions with no soil OC stock yet reported. We extrapolated SOC and DBD of the top $20 \mathrm{~cm}$ of the cores to $1 \mathrm{~m}$ depth and then compared the extrapolated soil OC stocks with the true soil OC stocks of the cores to evaluate the feasibility and accuracy of the method (Figure S1). Some of the top meter of VHC soils likely contain the "unvegetated period" in their bottoms due to their young ages and rapid sedimentation. However, the vertical distribution of $\mathrm{SOC}$ is also impacted by the vegetation through root penetration and dissolved organic carbon leaching processes. The slopes were close to 1 for mangrove and salt marsh soils but 0.84 for seagrass soils indicating that the methodology is generally acceptable. However, the soil OC stock of seagrass meadows may have been underestimated using this method since the slope was relatively low. We used the pedotransfer function of mangroves, salt marshes, and seagrasses in equations (SOC vs. DBD) derived from our sampled cores to estimate DBD from studies that did not report one (Figure S2). The comparisons of soil OC stocks among different data sources and distribution settings were conducted using analysis of variance in SPSS v. 20.0 (SPSS Inc.). Moreover, in the calculation of soil OC stocks, we used only soil core data without using surface soil data if both data were accessible at the same location. We calculated the soil OC stocks of VCHs for each province and aggregated them to acquire the national stocks.

Total areas of VCHs in China were sourced from published reports or scientific papers (Table S4). Moreover, if the area in a certain region was corrected or updated, we recalculated the total areas of $\mathrm{VCH}$ sy taking this updation into consideration. It should be noted that the second national wetland investigation, one of the major data sources on mangrove and salt marsh areas, did not cover habitat areas $<8$ ha (Table S4). The seagrass area was continually updated through the discovery of new seagrass habitats although no targeted national investigation has been conducted. Thus, the area data of Chinese VCHs used in the present study are conservative.

\subsection{Carbon accumulation rate calculation and synthesis of published literature}

The CFCS (Constant Flux Constant Sedimentation) model was used to calculate sedimentation accretion rates based on the distribution of ${ }^{210} \mathrm{~Pb}_{\text {ex }}$ activities with depth (Sanchez-Cabeza \& RuizFernández, 2012). However, ${ }^{210} \mathrm{~Pb}$ activities in two seagrass cores (S10 and S13) were generally low and could not be used to create a complete geochronology. This was attributed to the abundance of coarse soils which led to diluted ${ }^{210} \mathrm{~Pb}_{\mathrm{ex}}$-specific activities with depth (Arias-Ortiz, Masqué, et al., 2018). Thus, 14 out of the 16 soil cores dated were included in SAR estimation (Figure S3). Moreover, we also compiled SAR data from 73 soil cores from the published literature which focused on VCHs in China (Table S5). All 87 cores were used to estimate SAR over the last century. We used SOC content and SAR to calculate organic carbon accumulation rates (CARs) in soils of VCHs across China. As with the published cores which had no SOC or DBD data, we selected suitable soil OC stock data from our sampled cores nearby to make an approximate substitution. If SOC was reported but with no DBD, we used the pedotransfer function as described above to estimate DBD so that soil OC stocks could be calculated (Figure S2).

\subsection{Estimation of source identification and sequestration potential of soil OC stocks}

The relative contribution of coastal vegetation and terrestrial and marine organic matter (phytoplankton and macroalgae) to the carbon pools in the top meter of the soil profiles of the $\mathrm{VCHs}$ was estimated using two-tracer $\left(\delta^{13} \mathrm{C}, \mathrm{N} / \mathrm{C}\right.$ ratio) stable isotope analysis in $\mathrm{R}$ (MixSIAR), one of the more modern Bayesian mixing models (Stock \& Semmens, 2016). Bayesian mixing models incorporate both observed data and uncertainty to quantify the likelihood of a given solution, which is obtained from the posterior distribution (Stock \& Semmens, 2016). We used $\delta^{13} \mathrm{C}$ and N/C determined from our coastal vegetation samples and synthesized from the literature to calculate the blue carbon endmembers. Due to the large variation in $\delta^{13} \mathrm{C}$ and $\mathrm{N} / \mathrm{C}$ among plant tissues, we used the median values of isotope or N/C ratio since it was difficult to deduce undisputed fractionation factors for coastal vegetation. We assumed standard deviation $(S D)=0.5$ or 0.005 to reflect similar variability of the isotopic signatures or N/C ratios as for the replicated sources of OC (Röhr et al., 2018). We also synthesized $\delta^{13} \mathrm{C}$ and N/C data for riverine POM, phytoplankton, and macroalgae from the literature to generate terrestrial and marine endmembers. We used isotope or N/C ratio mean values and SDs for these endmembers. Phytoplankton and macroalgae were combined as a single $O C$ source since their published $\delta^{13} \mathrm{C}$ and N/C ratio endmembers greatly overlapped. Endmembers of coastal vegetation (plant tissue), terrestrial (terrestrial POM), and marine (phytoplankton and macroalgae) samples are presented in Tables S6-S8, respectively. 
Previous work (Xiong et al., 2018) and results from the present study jointly indicate that soil OC stocks of VCHs depended largely on autochthonous OC input. Thus, we derived regression models of autochthonous OC contribution versus soil OC stocks of soil cores (Figure S4) and estimated the potential soil OC stocks of VCHs assuming that the autochthonous OC contribution increased by $25 \%$ and $50 \%$. These assumptions may represent short-term (10-40 years) and long-term (40-100 years) scenarios of protection and restoration in VCHs. Moreover, we assumed that the area of $\mathrm{VCH}$ recovered to the level in the 1980s under the short-term scenario and to historical highest record levels under the long-term scenario to estimate the potential soil OC stocks of the habitats. The "National coastal shelterbelt system construction project planning (2016-2025)" had set a target area for restoration of mangroves (National Forestry Administration \& National Development and Reform Commission of China, 2015). We therefore adopted these data instead of the area in the 1980s to construct the short-term scenario.

\section{5 | Historical losses and carbon emission estimations}

Historical extents of mangrove in China are available in published sources but are notably scarce for salt marsh and seagrass meadows. We recalculated the historical extents of salt marsh based on the remote sensing interpreted "Marine marshes/mangrove" data, subtracting the extent of contemporary mangrove (Niu et al., 2012). If the area information from a certain region was absent, for example the mangrove areas of Taiwan, Hong Kong, and Macao in the 1950s, we used data from a closed period to substitute to make the historical areas comparable. We synthesized existing quantitative data on Chinese seagrass areal extent dynamics from 11 sites covering the time period 1982-2014 and deduced the Chinese seagrass rate of change $\left(-5.4 \%\right.$ year $^{-1}$, Table S9) following the methods of Waycott et al. (2009). We then estimated the historical extents of seagrass meadows in the 2000s, 1990s, and 1980s using this rate. Moreover, the seagrass area in the 1950s was estimated using rates of change between the global decadal seagrass $\left(1950-1980,-0.68 \%\right.$ year $^{-1}$ ) proposed by Waycott et al. (2009).
We calculated carbon stocks for the 1950s, 1980s, 1990s, 2000s, and 2010s based on the historical extent of VCHs for these decades. Soil LOC, including polysaccharides, proteins, and lipids with rapid turnover rates, is the most active fraction of $O C$ and is readily utilized by soil microorganisms (Harvey et al., 1995). Studies indicate that soil LOC is most susceptible to ecosystem degradation and landuse change (DeGryze et al., 2004). Thus, we assume the LOC pool $(0-100 \mathrm{~cm})$ to be capable of being entirely oxidized and lost to the atmosphere as $\mathrm{CO}_{2}$ when the ecosystem is degraded, representing the lower estimates of carbon loss (Table S10). We assume that the OC pool may be entirely oxidized and lost to the atmosphere as $\mathrm{CO}_{2}$ as the upper estimates of carbon loss. Potential $\mathrm{CO}_{2} \mathrm{e}$ emissions from $\mathrm{VCH}$ losses were estimated by first calculating the $\mathrm{OC}$ storage losses by decade and then multiplying the LOC ratio by 3.67 (the molecular weight ratio of $\mathrm{CO}_{2} \mathrm{e}$ to $\mathrm{C}$ ). $\mathrm{CO}_{2} \mathrm{e}$ emissions are reported as $\mathrm{CO}_{2} \mathrm{e}$ (or carbon dioxide equivalents) because $\mathrm{CO}_{2} \mathrm{e}$ is the most common and conservative C-based GHG (Kauffman \& Donato, 2012). Positive values correspond to $\mathrm{CO}_{2} \mathrm{e}$ emissions and negative values correspond to $\mathrm{CO}_{2}$ e sequestration.

\section{RESULTS}

\section{1 | SOC stocks and sources}

Soil organic carbon stocks were estimated from 55 sampled soil cores, 181 sampled surface soils and 207 published soil cores across different climatic zones, geomorphic settings, and vegetation types in China to provide unbiased quantification of soil carbon stock in the top meter of VCHs (Tables S1 and S2). Soil OC stocks estimated from the three data sources are not significantly different (mangrove $F=2.37, p=.96$; salt marsh $F=1.91, p=.15$; seagrass $F=0.08$, $p=.92$; Table S11). The data were therefore combined to yield comprehensive soil OC stock estimates in Chinese VCHs. Soil OC stocks in the top meter of $\mathrm{VCH}$ are skewed, ranging widely (Table 1). The mean $( \pm 95 \% \mathrm{Cl}$ ) soil OC stocks of mangrove, salt marsh, and seagrass are $190.8 \pm 23.5,81.1 \pm 9.1$ and $91.0 \pm 28.9 \mathrm{Mg} \mathrm{C} / \mathrm{ha}$, with median values of $156.1,65.3$, and $43.6 \mathrm{Mg} \mathrm{C} / \mathrm{ha}$, respectively. Combining the mean estimates with the estimated area of VCHs in each Chinese province (total areas: mangrove 35,537.1 ha, salt marsh 103,104.1 ha, seagrass 14,660.0 ha, Tables S4 and S12), we estimate the soils of VCHs in China to contain $6.3 \pm 0.6,7.5 \pm 0.6$, and $1.6 \pm 0.6 \mathrm{TgC}$

TABLE 1 Soil organic carbon stocks in Chinese vegetated coastal habitats

\begin{tabular}{|c|c|c|c|c|c|c|}
\hline Ecosystem & $\begin{array}{l}\text { No. } \\
\text { cores }^{a}\end{array}$ & $\begin{array}{l}\text { Range } \\
\text { (Mg C/ha) }\end{array}$ & $\begin{array}{l}\text { Mean } \pm 95 \% \\
\mathrm{Cl}(\mathrm{Mg} \mathrm{C} / \mathrm{ha})\end{array}$ & $\begin{array}{l}\text { Median } \\
\text { (Mg C/ha) }\end{array}$ & Area $^{b}$ (ha) & $\begin{array}{l}\text { Stock } \pm 95 \% \\
\mathrm{Cl}^{\mathrm{c}}(\mathrm{Tg})\end{array}$ \\
\hline Mangrove & 165 & $27.7-1,490.5$ & $190.8 \pm 23.5$ & 156.1 & $35,537.1$ & $6.3 \pm 0.6$ \\
\hline Salt marsh & 149 & $12.5-327.7$ & $81.1 \pm 9.1$ & 65.3 & $103,104.1$ & $7.5 \pm 0.6$ \\
\hline Seagrass & 40 & $11.7-360.0$ & $91.0 \pm 28.9$ & 43.6 & $14,660.0$ & $1.6 \pm 0.6$ \\
\hline
\end{tabular}

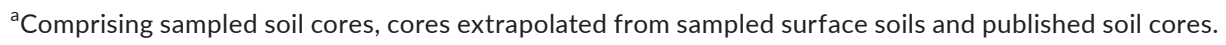

${ }^{\mathrm{b}}$ Area data are presented in Table S4.

${ }^{\mathrm{C}}$ Calculated based on province; detailed data are presented in Table S12. 
$( \pm 95 \% \mathrm{Cl})$ in the top meter, respectively, contributing approximately $0.24 \%, 0.12 \%-1.88 \%$, and $0.02 \%-0.04 \%$ of the total OC stored in the soils of mangroves, salt marshes, and seagrasses worldwide (Atwood et al., 2017; Duarte et al., 2013; Fourqurean et al., 2012).

Soils of Chinese VCHs have average $\delta^{13} \mathrm{C}$ values of $-24.7 \pm 1.9 \%$, $-22.7 \pm 1.2 \%$ o, $-21.0 \pm 1.3 \%$ o, $-19.4 \pm 3.2 \%$ (mean $\pm S D$ ) for all cores and subsample horizons ( $5 \mathrm{~cm}$ interval) of mangrove, $\mathrm{C}_{3}$ salt marsh, $\mathrm{C}_{4}$ salt marsh, and seagrass, respectively (Table $\mathrm{S} 1$ ). These $\delta^{13} \mathrm{C}$ values in the soils are significantly enriched (mangrove and $\mathrm{C}_{3}$ salt marsh) or depleted ( $\mathrm{C}_{4}$ salt marsh and seagrass) compared with the value of plant tissues (Table S6). The N/C ratios of mangrove, salt marsh, and seagrass soils were $0.020-0.180,0.032-1.055$, and $0.011-0.264$, with mean values of $0.071 \pm 0.024,0.127 \pm 0.090$, and $0.097 \pm 0.052$ (mean $\pm S D$ ), respectively (Table S1). The N/C ratios of mangrove, salt marsh, and seagrass soils are significantly higher than the value of plant tissues by 3-7 times (Table S6). The deviations in $\delta^{13} \mathrm{C}$ and $\mathrm{N} / \mathrm{C}$ values from those of the standing $\mathrm{VCH}$ vegetation are not merely due to the decomposition process, but indicate that the soil OC stocks are derived from mixtures of autochthonous and allochthonous sources. Using a three-source (autochthonous, terrestrial-derived, and marine-derived) Bayesian mixing model with two tracers ( $\delta^{13} \mathrm{C}$ and $\mathrm{N} / \mathrm{C}$ ratio), the average fractions of autochthonous OC in the soil cores were estimated to be $46 \pm 9 \%, 24 \pm 6 \%$, and $21 \pm 7 \%$ (mean $\pm S D$ ) in mangrove, salt marsh, and seagrass, respectively (Table S13). Terrestrial-derived OC is dominant in allochthonous sources in the soils of VCHs, accounting for $34 \pm 13 \%, 41 \pm 8 \%$, and $47 \pm 8 \%$ of OC stocks in soils of mangrove, salt marsh, and seagrass habitats, respectively.

\subsection{Spatial distribution of SOC stocks}

Vegetated coastal habitats are significantly different in terms of soil OC storage per unit area across climatic zones (mangrove, $F=7.91, p<.01$; salt marsh, $F=19.63, p<.001$; seagrass, $F=4.50$, $p<.05$; Figure 2a). Mangroves and seagrasses were found to have
FIGURE 2 Spatial distributions of soil organic carbon stocks of Chinese vegetated coastal habitats across (a) climatic zones, (b) geomorphic settings, and (c) plant species. Data are mean values $\pm S E$

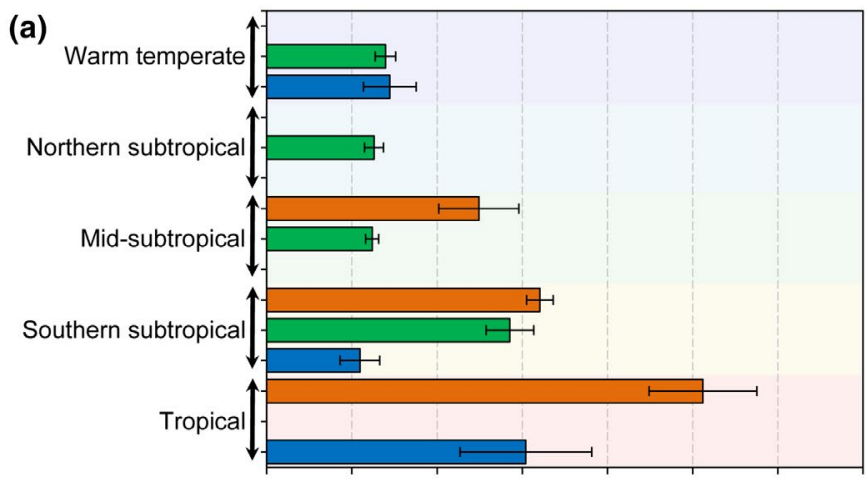

(b)

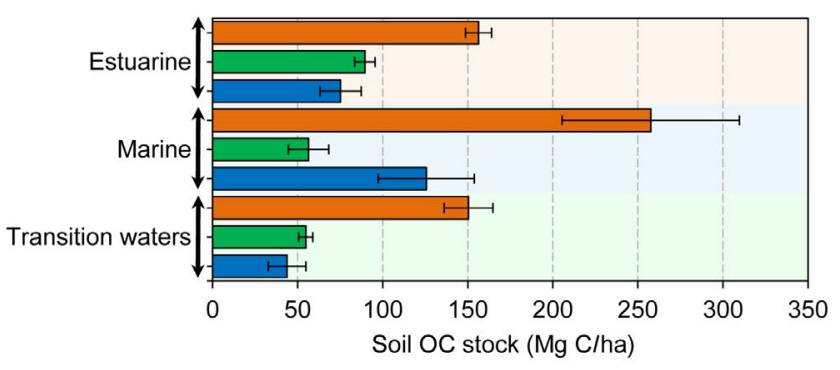

Soil OC stock

Mangrove

Salt marsh

Seagrass

(c)

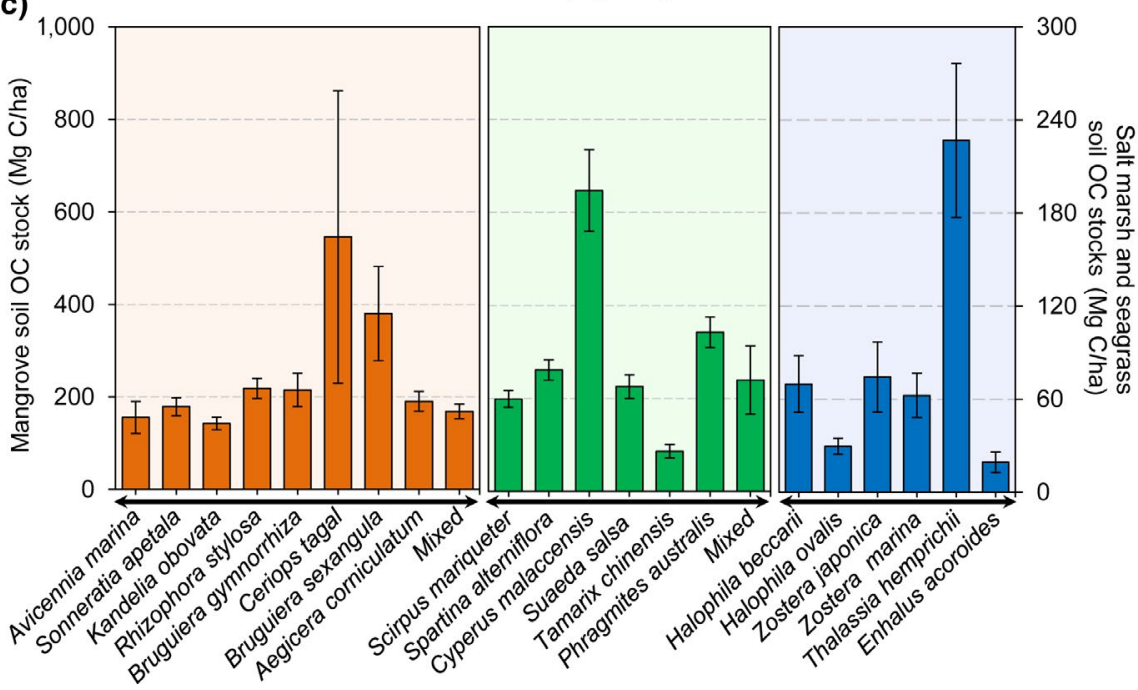


high soil OC stocks (mangrove, $256.1 \pm 31.6 \mathrm{Mg} \mathrm{C} /$ ha; seagrass, $152.1 \pm 38.6 \mathrm{Mg} \mathrm{C} /$ ha; mean $\pm \mathrm{SE}$ ) in the tropics but salt marshes have high soil OC stocks $(142.7 \pm 14.0 \mathrm{Mg} \mathrm{C} / \mathrm{ha})$ in the south subtropics. No significant differences in $\mathrm{VCH}$ soil OC stocks were detected among other zones. Soil OC stocks of $\mathrm{VCH}$ also vary significantly by geomorphology settings (mangrove, $F=7.48, p<.01$; salt marsh, $F=5.03, p<.01$; seagrass, $F=3.86, p<.05$; Figure $2 b$ ). Mangroves and seagrasses with marine settings have larger soil OC stocks (mangrove, $257.6 \pm 52.1 \mathrm{Mg} \mathrm{C} / \mathrm{ha}$; seagrass, $125.6 \pm 28.2 \mathrm{Mg} \mathrm{C} / \mathrm{ha}$ ) than those in estuarine and transition waters. By contrast, salt marshes within estuarine habitats exhibit higher stocks $(89.5 \pm 6.0 \mathrm{Mg} \mathrm{C} /$ ha) than those in marine and transition waters. Soil OC stocks in $\mathrm{VCHs}$ are found to be significantly different among plant species (mangrove, $F=5.19, p<.001$; salt marsh, $F=5.90, p<.001$; seagrass, $F=6.75, p<.001$; Figure $2 c$ ), being maximum in Ceriops tagal $(545.8 \pm 316.2 \mathrm{Mg} \mathrm{C} / \mathrm{ha})$, Cyperus malaccensis (194.2 $\pm 26.4 \mathrm{Mg}$ $\mathrm{C} / \mathrm{ha})$, and Thalassia hemprichii (226.9 $\pm 49.7 \mathrm{Mg} \mathrm{C} / \mathrm{ha})$, and minimum in Kandelia obovata $(142.8 \pm 13.6 \mathrm{Mg} \mathrm{C} / \mathrm{ha})$, Tamarix chinensis $(25.9 \pm 4.4 \mathrm{Mg} \mathrm{C} / \mathrm{ha})$, and Enhalus acoroides $(19.3 \pm 6.7 \mathrm{Mg} \mathrm{C} / \mathrm{ha})$ in mangrove, salt marsh, and seagrass soils, respectively.

\section{3 | Soil organic CARs}

The sediment accretion rates (SARs) in Chinese mangroves, salt marshes, and seagrasses vary widely, with mean values of 11.6 , 22.6 , and $15.8 \mathrm{~mm}$ /year, respectively (Table 2 ). The median of SARs is significantly lower than the mean value but still exceeds the rate of SLR in China (2.9 $\pm 0.8 \mathrm{~mm} /$ year, 1980-2016) by three to six times (Qu et al., 2019). However, it should be noted that mangrove and salt marsh (e.g., mangroves in Shankou and Qinglan Harbor; salt marshes in Duliujian River Estuary, and Laizhou Bay; Table S5) with low SAR might not be able to keep pace with SLR. The organic CARs are estimated at 28-840, 7-955, and 7-976 $\mathrm{g} \mathrm{C} \mathrm{m}^{-2}$ year ${ }^{-1}$, with median values of 124,154 , and $43 \mathrm{~g} \mathrm{C} \mathrm{m}^{-2}$ year $^{-1}$ in mangrove, salt marsh, and seagrass habitats, respectively. A five-time discrepancy is found between the mean and the median values of the CAR of seagrass habitats. This is attributed to the extreme values observed in the Zostera japonica and Zostera marina meadows in Swan Lake, Shandong Province (Table S5). However, CAR estimation of seagrasss soils is conservative due to lack of data on T. hemprichii and Halophila beccarii meadows. Combining the estimated median carbon burial rates with the area occupied by the different habitats, we estimate that mangrove, salt marsh, and seagrass soils in China bury $44 \pm 17,159 \pm 57$ and $6 \pm 45$ (mean $\pm 95 \% \mathrm{Cl}) \mathrm{Gg} \mathrm{C} /$ year.

\subsection{SOC loss during the last 70 years and sequestration potential}

Chinese mangrove habitats experienced sustained deforestation during the second half of the 20th century (1950s-1990s, deforestation rate 691 ha/year), shifting to a modest expansion through restoration over the last decade of the 20th century (1990-2000s, restoration rate 828 ha/year), and accelerated restoration rates in the 21st century (2000s-2010s, restoration rate 1,266 ha/year; Table 3). When combined with per area soil OC stocks, the stock changed at $-132,+158$ and $+242 \mathrm{Gg} \mathrm{C}$ annually for 1950s-1990s, 1990s-2000s, and 2000s-2010s, respectively. This equates to potential $\mathrm{CO}_{2}$ e emissions of $151-484 \mathrm{Gg}$ /year during the $1950 \mathrm{~s}-1990 \mathrm{~s}$ and potential sequestration of 580 and $887 \mathrm{Gg}$ /year during 1990s2000 s and 2000s-2010s, respectively. We calculate that mangrove restoration has sequestered $14.7 \mathrm{Tg}$ of $\mathrm{CO}_{2} \mathrm{e}$ from the atmosphere directly or indirectly, which may compensate at least $76 \%$ of the preceding $\mathrm{CO}_{2} \mathrm{e}$ emissions (Table S14). Salt marsh habitats in China have suffered great losses in the past 70 years without experiencing any appreciable recovery. Area loss rate is estimated to have been relatively stable during the 1950s-1980s (28,893 ha/year) and 1980s1990 s (22,279 ha/year) then to have declined to $8,928 \mathrm{ha} /$ year in the 1990s-2000s. This corresponds to 2,021-8,600, 1,558-6,631, and 624-2,657 Gg/year $\mathrm{CO}_{2}$ e emissions for each period and a total of 82.5-350.9 $\mathrm{Tg} \mathrm{CO}_{2}$ e emitted throughout 70 years. Nonetheless, over half of the recent salt marsh habitat is occupied by the invasive species S. alterniflora introduced in 1979 (Chung, 2006; Liu et al., 2018), thus the decline in native salt marsh is larger. However, the higher CAR of S. alterniflora may have offset net $\mathrm{CO}_{2} \mathrm{e}$ emissions of native salt marshes. We lack estimates of the loss rates of seagrass meadows but, based on the Chinese and global decadal seagrass rates of decline (Table S9; Waycott et al., 2009), seagrass habitats in China are estimated to have disappeared at rates of 533-3,100 ha/year in the 1950s-2010s. This rough estimate is equivalent to $40-1,035 \mathrm{Gg}$ $\mathrm{CO}_{2}$ e emissions annually and 5.7-25.2 $\mathrm{Tg} \mathrm{CO}_{2}$ e emissions in total.

The soil OC sequestration potential of Chinese VCHs was estimated based on the model of autochthonous contribution versus soil OC stock (Figure S4). Under the "short-term" scenario (assuming that autochthonous-derived OC increased by $25 \%$ ), the soil

TABLE 2 Sediment accretion rate and organic carbon burial rate of Chinese vegetated coastal habitats

\begin{tabular}{|c|c|c|c|c|c|c|c|c|}
\hline \multirow[b]{2}{*}{ Ecosystem } & \multirow[b]{2}{*}{ No. cores } & \multicolumn{3}{|c|}{$\begin{array}{l}\text { Sediment accretion rate } \\
\text { (mm/year) }\end{array}$} & \multicolumn{3}{|c|}{$\begin{array}{l}\text { OC accumulation rate } \\
\left(\mathrm{gC} \mathrm{m}^{-2} \text { year }^{-1}\right)\end{array}$} & \multirow{2}{*}{$\begin{array}{l}\text { Total } \mathrm{OC} \text { accumulation } \\
\text { rate (Gg C/year) } \\
\text { Mean } \pm 95 \% \mathrm{Cl}\end{array}$} \\
\hline & & Range & Mean & Median & Range & Mean & Median & \\
\hline Mangrove & 40 & $1.9-56.4$ & 11.6 & 9.7 & $28-840$ & 163 & 124 & $44 \pm 17$ \\
\hline Salt marsh & 41 & $2.3-90.0$ & 22.6 & 16.3 & $7-955$ & 201 & 154 & $159 \pm 57$ \\
\hline Seagrass & 6 & $5.9-40.0$ & 15.8 & 11.8 & $7-976$ & 202 & 43 & $6 \pm 45$ \\
\hline
\end{tabular}

Note: Detailed sediment and carbon accumulation rates data are presented in Table S5. 
TABLE 3 Soil organic carbon losses in the vegetated coastal habitats of China in the past 70 years

\begin{tabular}{|c|c|c|c|c|c|c|}
\hline Period & \multicolumn{3}{|c|}{ Area loss rate (ha/year) } & \multicolumn{3}{|c|}{$\mathrm{CO}_{2}$ emission rate (Gg/year) } \\
\hline $1950 s-1980 s$ & $691^{a}$ & $28,893^{\mathrm{d}, \mathrm{e}}$ & $533^{f}$ & $151-484$ & $2,021-8,600$ & $40-178$ \\
\hline $1980 s-1990 s$ & $691^{\mathrm{a}}$ & $22,279^{e}$ & $3,100^{f, g}$ & $151-484$ & $1,558-6,631$ & $235-1,035$ \\
\hline $1990 s-2000 s$ & $-828^{a, b}$ & $8,928^{e}$ & $1,800^{\mathrm{g}}$ & -580 & $624-2,657$ & $136-601$ \\
\hline $2000 s-2010 s$ & $-1,266^{b, c}$ & $-38^{\mathrm{c}, \mathrm{e}}$ & $1,034^{\mathrm{g}}$ & -887 & -11 & $78-345$ \\
\hline
\end{tabular}

Note: Detailed data on soil organic carbon stocks and losses of vegetated coastal habitats in China are presented in Table S14.

aLiao and Zhang (2014).

${ }^{\text {b}}$ Chen et al. (2009).

'Table S4.

${ }^{d}$ Yang and Chen (1995).

eBased on Niu et al. (2012).

${ }^{\mathrm{f}}$ Based on Waycott et al. (2009).

${ }^{\mathrm{g}}$ Based on Chinese seagrass rate of change (Table S9).

OC stocks of mangrove, salt marsh, and seagrass in China were estimated to be $202.7 \pm 165.6,160.6 \pm 29.7$, and $107.3 \pm 47.9 \mathrm{Mg}$ $\mathrm{C} /$ ha (mean $\pm 95 \% \mathrm{Cl}$; Table S15). If the habitats of mangrove, salt marsh, and seagrass were to recover to the extent of these habitats in the 1980s (84,187, 414,803, and 74,000 ha, respectively), soil OC stocks would increase to $17.1 \pm 1.4,66.6 \pm 12.3$, and $7.9 \pm 3.5 \mathrm{Tg}$ $\mathrm{C}$, respectively. Under the "long-term" scenario (assuming that autochthonous-derived OC increased by $50 \%$ ), the soil OC stocks of mangrove, salt marsh, and seagrass in China would be expected to reach $226.2 \pm 11.3,416.2 \pm 76.9$, and $300.2 \pm 131.5 \mathrm{Mg} \mathrm{C} / \mathrm{ha}$. If the habitats of mangrove salt marsh and seagrass were to recover to the largest area on record $(250,000,1,281,600$, and 90,000 ha, respectively), the soil OC stocks would approach $56.6 \pm 2.8,533.5 \pm 98.6$, and $27.0 \pm 11.8 \mathrm{Tg}$ in Chinese mangrove, salt marsh, and seagrass, respectively. About 279.7 and 2,208.2 $\mathrm{Tg} \mathrm{CO}_{2} \mathrm{e}$ could theoretically be stored in the top meter of the soil profile of $\mathrm{VCH}$ under the short- and long-term scenarios, respectively.

\section{DISCUSSION}

The present study provides the most comprehensive assessment to date of soil OC stocks and sequestration rates in Chinese VCHs. The estimated soil OC stocks are lower than previously reported estimates by $79.6-153.9,53.3$, and $84.1 \mathrm{Mg} \mathrm{C} /$ ha for mangrove, salt marsh, and seagrass (Liu et al., 2014; Meng et al., 2019), respectively, likely resulting from limited data used earlier including geographic biases toward carbon-rich sites that may lead to overestimation of the soil OC stocks. We found the soil OC stocks of Chinese VCHs to be within the range of the values from global estimates, but the mean values are well below reported global averages (mangrove $283 \pm 193 \mathrm{Mg} \mathrm{C} / \mathrm{ha}$, salt marsh $162 \mathrm{Mg} \mathrm{C} / \mathrm{ha}$, seagrass $139.7 \mathrm{Mg} \mathrm{C} /$ ha; Atwood et al., 2017; Duarte et al., 2013; Fourqurean et al., 2012). This suggests that $\mathrm{VCH}$ in China are not as efficient in accumulating organic matter in the underlying soils as those elsewhere, but may also signal bias in existing global assessments, which do not yet include salt marsh and seagrass (Duarte et al., 2013; Fourqurean et al., 2012) or only include a few values for mangrove (Atwood et al., 2017) from Chinese VCHs. Indeed, we also demonstrate that organic CARs of VCHs in China are lower than the global mean values (mangrove $163 \mathrm{~g} \mathrm{C} \mathrm{m}^{-2}$ year $^{-1}$, salt marsh $244.7 \pm 26.1 \mathrm{~g} \mathrm{C} \mathrm{m}^{-2}$ year $^{-1}$, seagrass $138 \pm 38 \mathrm{~g} \mathrm{C} \mathrm{m}^{-2}$ year $^{-1}$; Duarte et al., 2013; Ouyang \& Lee, 2014), although the SARs are much higher than those elsewhere (mangrove $6.73 \mathrm{~mm} /$ year, salt marsh $5.47 \mathrm{~mm}$ /year, seagrass $2.02 \mathrm{~mm}$ /year; Duarte et al., 2013), likely due to important inputs of land-derived sediments, consistent with the significant contribution of terrestrial carbon in the VCH soil stocks. However, the CARs of Chinese VCHs are still significantly higher than those of agricultural land (14 g C m${ }^{-2}$ year $^{-1}$ ), shrubland $\left(18 \mathrm{~g} \mathrm{C} \mathrm{m}^{-2}\right.$ year $\left.^{-1}\right)$, or forest (20 g C m$~^{-2}$ year $^{-1}$ ) soils (Piao et al., 2009; Yang et al., 2014; Zhao et al., 2018), supporting the importance of VCHs in China as intense OC sinks at the regional scale.

Our results suggest that present soil OC stocks of Chinese VCHs are governed by biogeographic, sedimentary, and anthropic driving factors. Higher temperature and precipitation enhance primary production of coastal vegetation and lengthen the soil inundation periods (Macreadie et al., 2019; Osland et al., 2018; Ouyang \& Lee, 2014; Sanders et al., 2016), resulting in higher soil OC stocks of VCHs in tropical (mangrove and seagrass) or subtropical (salt marsh) regions. However, climate cannot fully explain the distribution pattern of soil OC stocks since no clear difference was observed in other climatic zones suggesting that climate is not the dominant factor controlling soil OC stock distributions. Variability in OC stocks of VCHs is also governed by community structure, reflecting differences in productivity and sediment trapping capabilities among plant species (Chmura et al., 2003; Kirwan et al., 2016; Lavery et al., 2013; Osland et al., 2018). It must be stressed here that S. alterniflora invasions have altered the community composition of salt marsh and mangrove in China especially at the southern coast where the intertidal zone is narrow and formed mainly in the bay as a result of the low Holocene basement (Gao et al., 2014). Spartina alterniflora marsh, with medium soil OC stocks $(78.4 \pm 6.6 \mathrm{Mg} \mathrm{C} / \mathrm{ha})$ but high 
CAR $\left(297 \pm 203\right.$ g C m$^{-2}$ year $\left.^{-1}\right)$, accounts for approximately $57 \%$ $(4.3 \pm 0.4 \mathrm{Tg})$ of the total OC stock and at least $33 \%(162 \pm 111 \mathrm{Gg}$ $\mathrm{C} /$ year) of the total OC burial of salt marshes. However, the effect of S. alterniflora invasion on soil OC stocks is not uniform. Expansion of S. alterniflora into unvegetated mudflats offsets to some degree the reclamation-induced habitat loss, increasing soil OC pools with increasing invasion ages (Liu, Han, et al., 2017). Spartina alterniflora displacement of native species with low soil OC stocks such as $T$. chinensis, S. mariqueter, and S. salsa can also increase soil OC stocks but reduce soil $O C$ stocks when displacing native species with higher soil OC stocks (such as C. malaccensis, P. australis, and mangroves). Collectively, these results reinforce the biogeographic impacts on $\mathrm{OC}$ stocks of $\mathrm{VCH}$.

High terrestrial sediment supply is a distinct feature of the Chinese coastal zone. Due to natural and human-induced erosion, Chinese coastal rivers account for nearly $12 \%$ of the global sediment delivered into the ocean (Milliman \& Farnsworth, 2013), accounting for the very high SARs of the $\mathrm{VCH}$ s which are about two to seven times faster than reported global average values (Duarte et al., 2013). The particulate organic carbon (POC) content of suspended sediment typically decreases with higher suspended sediment loads in rivers (Marwick et al., 2015). This explains the high SARs but low soil OC stocks in Chinese VCHs since terrestrial derived sediments are depleted in OC. The high contribution of terrestrial sediments may explain why estuarine mangroves or seagrass have lower soil OC stocks than marine ones. The lower soil OC stock in Chinese salt marsh is largely dependent on terrestrial-derived sources, thus estuarine sites which contain finer-grained sediments and higher contributions of refractory allochthonous OC should have higher stocks (Macreadie, Ollivier, et al., 2017). However, the construction of large reservoirs and dams, water resource utilization, and water-soil conservation in China have drastically reduced sediment inputs by $\sim 85 \%$ (Wu et al., 2020), and this may reduce the SARs of $\mathrm{VCH}$ and, therefore, their capacity to offset SLR (Kirwan et al., 2016) as the decline in sediment delivery may coincide with the forecast acceleration of SLR with climate change. More urgently, widely occurring flood-defense barriers in the Chinese coastal zone would impede the vegetation from landward migrating, leading to catastrophic threats to the VCHs with rising sea level. Specifically, $\sim 80 \%$ of the mangroves and large portions of the salt marshes from China exist in front of the embankments (Wang \& Wang, 2007), suggesting high vulnerabilities in response to future decline in sediment input and SLR.

Rapid coastal development in modern China during the past decades has resulted in a loss of over 23,000 ha/year of tidal flats reclaimed for aquaculture, agriculture, salt pans, and urban expansion from 1950 to 2008 (Wang et al., 2014). During this period, salt marshes have declined more rapidly than mangroves and seagrasses, likely due to their wider distribution on the coast (except for the tropical zone). Sequential reclamation also drives conversion or destruction of landward mature habitats which are likely to have higher soil OC stocks (Liu, Han, et al., 2017; Wang et al., 2013), leaving seaward immature or newborn habitats with low soil OC stocks dominating in some areas. Although the policies of the Chinese government have changed from encouraging human reclamation to prohibiting any form of illegal land reclamation program from national to local scales, some already launched reclamation projects remain in progress. For example, a further 6,500 ha of sea area is earmarked for reclamation in the Caofeidian Industrial Complex in Hebei province until 2030 (Li et al., 2020), and this may destroy the largest seagrass habitats recorded in China (Long Island seagrass habitat, 2,917 ha, Zhou et al., 2018). Economic development also leads to widespread coastal eutrophication (Xiao et al., 2019), resulting in habitat and soil OC stock losses (Deegan et al., 2012). For example, nutrient emission from aquaculture ponds or farms leads to further $\mathrm{VCH}$ losses and stimulates the decomposition of buried organic matter (Atwood et al., 2017; Liu, Jiang, et al., 2017). China has the largest aquaculture industry worldwide, mainly concentrated in the Bohai Rim, Jiangsu coastal plain, and Guangdong coastal region where VCHs are also rich (Duan et al., 2020), thus suggesting further potential losses of soil OC stocks of $\mathrm{VCH}$ in these regions.

Although the OC sink capacity of Chinese vegetated coastal habitats is presently limited, China has ample scope to expand this OC sink potential and, thereby, contribute to climate change mitigation and adaptation. Indeed, China has the second largest tidal flat globally $\left(12,049 \mathrm{~km}^{2}\right.$; Murray et al., 2019), suggesting some possible potential for $\mathrm{VCH}$ restoration. Moreover, coastal aquaculture ponds in China total 15,633 $\mathrm{km}^{2}$ (Duan et al., 2020), providing extensive potential accommodation space for $\mathrm{VCH}$ propagation and restoration (Fan \& Wang, 2017). The reversion from losses of mangroves and salt marshes to gains results from policies of the Chinese government since the 1990s to promote the protection and restoration of these habitats through the establishment of nature reserves to prevent habitat and soil OC stock losses (Zhou et al., 2016). A total of 34 mangrove reserves with a protected area $>1,238 \mathrm{~km}^{2}$ have been established in China, but there has been much less protection of salt marshes and seagrasses (Zhou et al., 2016). Moreover, over 500 projects have been conducted to restore the VCHs in China (Liu et al., 2016), suggesting a substantial national effort to enhance VCH OC stocks and their additional benefits. During the National Thirteenth Five-Year Plan period (2016-2020), China is promoting large-scale restoration projects termed "Blue bay," "Southern mangrove/Northern Tamarink," and "Ecological reef" (National Development \& Reform Commission of China, 2016). These national programs provide a major impetus for $\mathrm{VCH}$ restoration and will contribute to achieving national climate targets in the Paris Agreement. However, the planning, techniques, research/ assessment, and participation models underlying current restoration remain inadequate to effectively restore the coastal vegetated ecosystems (Liu et al., 2016). Demands for food and space continue to rise with further national economic development, and this may conflict for space and impede the full restoration of VCHs. Thus, efforts to conserve and restore Chinese VCHs should concentrate tactically on reducing losses and achieving habitat 
gains in areas with high soil $O C$ stock and burial rate potentials. The recovery of $\mathrm{VCH}$ can also be reconciled with demands for food and space by designing ecological aquaculture systems that accommodate VCHs (Fan \& Wang, 2017). Conservation of VCHs should also focus on watershed management and catchment-level approaches, maintaining terrestrial sediment inputs while reducing excess nutrient inputs (Macreadie, Nielsen, et al., 2017). In addition, we should note that soil OC deposits take tens of thousands of years to form and, once disrupted, they cannot be regained over short timescales by simply restoring the forest or grass. These restoration targets, if achieved, will have positive effects on China's future climate-change policy, businesses, and industries, and also contribute to the mitigation of global climate change and provide adaptive capacity to rising sea levels and increasing cyclones.

Blue carbon scientists across the world have been working to better quantify the carbon inventories and fluxes present in VCHs to fully exploit their climate mitigation potential (Macreadie et al., 2019). In the last decade an increasing number of SOC inventories have been conducted for $\mathrm{VCH}$ s at global, national, regional, and local scales (Atwood et al., 2017; Fourqurean et al., 2012; Hamilton \& Friess, 2018; Liu, Han, et al., 2017; Murdiyarso et al., 2015; Serrano et al., 2019), but fewer have been implemented in highly sedimentary environments. Chinese VCHs, which are characterized by high SARs but low soil OC stocks in various climatic regions and administrative jurisdictions, provide important insights into global blue carbon sink mechanisms and sequestration capacities. Our results distract from the existing bias toward highly productive environments where most research efforts have been made (Arias-Ortiz, Serrano, et al., 2018; Fourqurean et al., 2012; Murdiyarso et al., 2015), thus contributing to synchronous progression of global blue carbon estimation and management. Our results also highlight the differential effects of $S$. alterniflora invasion on blue carbon stocks, suggesting conservation strategies that need to balance management decisions involving invasion, OC stocks, and habitat functions in the foreseeable highly invaded world. The reversion or remission of $\mathrm{VCH}$ losses in China demonstrates the potential of conservation and restoration of $\mathrm{VCHs}$ to underpin national policy development for reducing GHG emissions and enhancing ecosystem services. Within the context of climate change, restoration of historic losses of $\mathrm{VCHs}$ together with enhanced conservation of threatened VCHs which constitute the mechanism of the blue carbon strategy, may mitigate national $\mathrm{CO}_{2}$ emissions while providing additional benefits such as coastal protection from SLR and increased storms, improved water quality, and increased biodiversity and fishery resources.

\section{ACKNOWLEDGEMENTS}

This work was supported by the National Natural Science Foundation of China (no. 41991330, 41701263) and the Key Research Projects of Frontier Science, Chinese Academy of Sciences (no. QYZDJ-SSWDQC015). We thank Professor Bo Li at Fudan University; Professor Hangqing Fan at Guangxi Mangrove Research Center, Guangxi Academy of Sciences; Professor Chuan Tong at Fujian Normal
University; Professor Guo Wang at Fujian A\&F University; Professor Qiuying Han at Hainan Tropical Ocean University; Dr. Zhijian Jiang at South Sea Institute of Oceanology, Chinese Academy of Sciences (CAS), and Professor Guangxuan Han at Yantai Institute of Coastal Zone Research, CAS for their assistance in field sampling.

\section{CONFLICT OF INTEREST}

The authors declare no conflict of interest.

\section{AUTHOR CONTRIBUTION}

Y.M.L. designed this study. C.F., Y.L., L.Z., Q.Z. and K.X. conducted the fieldwork and/or laboratory measurements. L.Z. derived the dating models. C.F. analyzed the data and drafted the first version of the manuscript. Y.M.L., C.M.D., J.W., Y.L., L.Z., H.Z., C.T. and P.C. contributed to the writing and editing of the manuscript. All authors agree to the final manuscript.

\section{DATA AVAILABILITY STATEMENT}

The data that support the findings of this study are available from the corresponding author upon reasonable request.

\section{ORCID}

Chuancheng Fu iD https://orcid.org/0000-0001-5982-6809

Peter Christie iD https://orcid.org/0000-0002-1939-7277

Yongming Luo (iD https://orcid.org/0000-0002-2217-3207

\section{REFERENCES}

Arias-Ortiz, A., Masqué, P., Garcia-Orellana, J., Serrano, O., Mazarrasa, I., Marbà, N., \& Duarte, C. M. (2018). Reviews and syntheses: ${ }^{210} \mathrm{~Pb}-$ derived sediment and carbon accumulation rates in vegetated coastal ecosystems-setting the record straight. Biogeosciences, 15, 6791-6818. https://doi.org/10.5194/bg-15-6791-2018

Arias-Ortiz, A., Serrano, O., Masqué, P., Lavery, P. S., Mueller, U., Kendrick, G. A., Rozaimi, M., Esteban, A., Fourqurean, J. W., Marbà, N., Mateo, M. A., Murray, K., Rule, M. J., \& Duarte, C. M. (2018). A marine heatwave drives massive losses from the world's largest seagrass carbon stocks. Nature Climate Change, 8, 338. https://doi. org/10.1038/s41558-018-0096-y

Atwood, T. B., Connolly, R. M., Almahasheer, H., Carnell, P. E., Duarte, C. M., Ewers Lewis, C. J., Irigoien, X., Kelleway, J. J., Lavery, P. S., Macreadie, P. I., Serrano, O., Sanders, C. J., Santos, I., Steven, A. D. L., \& Lovelock, C. E. (2017). Global patterns in mangrove soil carbon stocks and losses. Nature Climate Change, 7, 523-528. https://doi. org/10.1038/NCLIMATE3326

Blair, G. J., Lefroy, R. D., \& Lisle, L. (1995). Soil carbon fractions based on their degree of oxidation, and the development of a carbon management index for agricultural systems. Australian Journal of Agricultural Research, 46, 1459-1466. https://doi.org/10.1071/AR9951459

Carnell, P. E., Windecker, S. M., Brenker, M., Baldock, J., Masque, P., Brunt, K., \& Macreadie, P. I. (2018). Carbon stocks, sequestration, and emissions of wetlands in south eastern Australia. Global Change Biology, 24, 4173-4184. https://doi.org/10.1111/gcb.14319

Chen, L., Wang, W., Zhang, Y., \& Lin, G. (2009). Recent progresses in mangrove conservation, restoration and research in China. Journal of Plant Ecology, 2, 45-54. https://doi.org/10.1093/jpe/rtp009

Chmura, G. L., Anisfeld, S. C., Cahoon, D. R., \& Lynch, J. C. (2003). Global carbon sequestration in tidal, saline wetland soils. Global Biogeochemical Cycles, 17, 1111. https://doi.org/10.1029/2002GB001917 
Chung, C. H. (2006). Forty years of ecological engineering with Spartina plantations in China. Ecological Engineering, 27, 49-57. https://doi. org/10.1016/j.ecoleng.2005.09.012

Deegan, L. A., Johnson, D. S., Warren, R. S., Peterson, B. J., Fleeger, J. W., Fagherazzi, S., \& Wollheim, W. M. (2012). Coastal eutrophication as a driver of salt marsh loss. Nature, 490, 388-392. https://doi. org/10.1038/nature11533

DeGryze, S., Six, J., Paustian, K., Morris, S. J., Paul, E. A., \& Merckx, R. (2004). Soil organic carbon pool changes following land-use conversions. Global Change Biology, 10, 1120-1132. https://doi.org/ 10.1111/j.1529-8817.2003.00786.x

Duan, Y., Li, X., Zhang, L., Chen, D., Liu, S., \& Ji, H. (2020). Mapping national-scale aquaculture ponds based on the Google Earth Engine in the Chinese coastal zone. Aquaculture, 520, 734666. https://doi. org/10.1016/j.aquaculture.2019.734666

Duarte, C. M., Losada, I. J., Hendriks, I. E., Mazarrasa, I., \& Marbà, N. (2013). The role of coastal plant communities for climate change mitigation and adaptation. Nature Climate Change, 3, 961-968. https:// doi.org/10.1038/NCLIMATE1970

Fan, H., \& Wang, W. (2017). Some thematic issues for mangrove conservation in China. Journal of Xiamen University: Natural Science, 56, 323 330 (in Chinese). https://doi.org/10.6043/j.issn.0438-0479.20161 2003

Fourqurean, J. W., Duarte, C. M., Kennedy, H., Marbà, N., Holmer, M., Mateo, M. A., Apostolaki, E. T., Kendrick, G. A., Krause-Jensen, D., McGlathery, K. J., \& Serrano, O. (2012). Seagrass ecosystems as a globally significant carbon stock. Nature Geoscience, 5, 505-509. https://doi.org/10.1038/ngeo1477

Gao, S., Du, Y., Xie, W., Gao, J., Wang, D., \& Wu, X. (2014). Environmentecosystem dynamic processes of Spartina alterniflora salt-marshes along the eastern China coastlines. Science China: Earth Sciences, 57, 2567-2586. https://doi.org/10.1007/s11430-014-4954-9

Hamilton, S. E., \& Friess, D. A. (2018). Global carbon stocks and potential emissions due to mangrove deforestation from 2000 to 2012 Nature Climate Change, 8, 240-244. https://doi.org/10.1038/s4155 8-018-0090-4

Harvey, H. R., Tuttle, J. H., \& Bell, J. T. (1995). Kinetics of phytoplankton decay during simulated sedimentation: Changes in biochemical composition and microbial activity under oxic and anoxic conditions. Geochimica et Cosmochimica Acta, 59, 3367-3377. https://doi. org/10.1016/0016-7037(95)00217-N

Hayes, M. A., Jesse, A., Hawke, B., Baldock, J., Tabet, B., Lockington, D., \& Lovelock, C. E. (2017). Dynamics of sediment carbon stocks across intertidal wetland habitats of Moreton Bay, Australia. Global Change Biology, 23, 4222-4234. https://doi.org/10.1111/gcb.13722

Howard, J., Hoyt, S., Isensee, K., Telszewski, M., \& Pidgeon, E. (2014). Coastal blue carbon: Methods for assessing carbon stocks and emissions factors in mangroves, tidal salt marshes, and seagrasses. Conservation International, Intergovernmental Oceanographic Commission of UNESCO, International Union for Conservation of Nature.

Jiao, N., Liang, Y., Zhang, Y., Liu, J., Zhang, Y., Zhang, R., Zhao, M., Dai, M., Zhai, W., Gao, K., Song, J., Yuan, D., Li, C., Lin, G., Huang, X. Yan, H., Hu, L., Zhang, Z., Wang, L., ... Zhang, S. I. (2018). Carbon pools and fluxes in the China Seas and adjacent oceans. Science China Earth Sciences, 61, 1535-1563. https://doi.org/10.1007/s1143 0-018-9190-x

Kauffman, J. B., \& Donato, D. C. (2012). Protocols for the measurement, monitoring and reporting of structure, biomass, and carbon stocks in mangrove forests. CIFOR.

Kauffman, J. B., Heider, C., Norfolk, J., \& Payton, F. (2014). Carbon stocks of intact mangroves and carbon emissions arising from their conversion in the Dominican Republic. Ecological Applications, 24, 518-527. https://doi.org/10.1890/13-0640.1

Kennedy, H., Beggins, J., Duarte, C. M., Fourqurean, J. W., Holmer, M., Marbà, N., \& Middelburg, J. J. (2010). Seagrass sediments as a global carbon sink: Isotopic constraints. Global Biogeochemical Cycles, 24 GB4026. https://doi.org/10.1029/2010GB003848

Kirwan, M. L., Temmerman, S., Skeehan, E. E., Guntenspergen, G. R., \& Fagherazzi, S. (2016). Overestimation of marsh vulnerability to sea level rise. Nature Climate Change, 6, 253-260. https://doi.org/ 10.1038/NCLIMATE2909

Lavery, P. S., Mateo, M. Á., Serrano, O., \& Rozaimi, M. (2013). Variability in the carbon storage of seagrass habitats and its implications for global estimates of blue carbon ecosystem service. PLoS ONE, 8 , e73748. https://doi.org/10.1371/journal.pone.0073748

Li, F., Ding, D., Chen, Z., Chen, H., Shen, T., Wu, Q., \& Zhang, C. (2020). Change of sea reclamation and the sea-use management policy system in China. Marine Policy, 115, 103861. https://doi.org/10.1016/j. marpol.2020.103861

Liao, B., \& Zhang, Q. (2014). Area, distribution and species composition of mangroves in China. Wetland Science, 12, 435-440 (in Chinese). https://doi.org/10.13248/j.cnki.wetlandsci.2014.04.005

Liu, H., Ren, H., Hui, D., Wang, W., Liao, B., \& Cao, Q. (2014). Carbon stocks and potential carbon storage in the mangrove forests of China. Journal of Environmental Management, 133, 86-93. https://doi. org/10.1016/j.jenvman.2013.11.037

Liu, J., Han, R., Su, H., Wu, Y., Zhang, L., Richardson, C. J., \& Wang, G. (2017). Effects of exotic Spartina alterniflora on vertical soil organic carbon distribution and storage amount in coastal salt marshes in Jiangsu, China. Ecological Engineering, 106, 132-139. https://doi. org/10.1016/j.ecoleng.2017.05.041

Liu, M., Mao, D., Wang, Z., Li, L., Man, W., Jia, M., Ren, C., \& Zhang, Y. (2018). Rapid invasion of Spartina alterniflora in the coastal zone of mainland China: New observations from Landsat OLI images. Remote Sensing, 10, 1933. https://doi.org/10.3390/rs10121933

Liu, S., Jiang, Z., Wu, Y., Zhang, J., Arbi, I., Ye, F., Huang, X., \& Macreadie, P. I. (2017). Effects of nutrient load on microbial activities within a seagrass-dominated ecosystem: Implications of changes in seagrass blue carbon. Marine Pollution Bulletin, 117, 214-221. https://doi org/10.1016/j.marpolbul.2017.01.056

Liu, Z., Cui, B., \& He, Q. (2016). Shifting paradigms in coastal restoration: Six decades' lessons from China. Science of the Total Environment, 566-567, 205-214. https://doi.org/10.1016/j.scitotenv. 2016.05.049

Macreadie, P. I., Anton, A., Raven, J. A., Beaumont, N., Connolly, R. M., Friess, D. A., Kelleway, J. J., Kennedy, H., Kuwae, T., Lavery, P. S., Lovelock, C. E., Smale, D. A., Apostolaki, E. T., Atwood, T. B., Baldock, J., Bianchi, T. S., Chmura, G. L., Eyre, B. D., Fourqurean, J. W., ... Duarte, C. M. (2019). The future of Blue Carbon science. Nature Communications, 10, 1-13. https://doi.org/10.1038/s41467-01911693-w

Macreadie, P. I., Nielsen, D. A., Kelleway, J. J., Atwood, T. B., Seymour, J. R., Petrou, K., Connolly, R. M., Thomson, A. C. G., Trevathan-Tackett, S. M., \& Ralph, P. J. (2017). Can we manage coastal ecosystems to sequester more blue carbon? Frontiers in Ecology and the Environment, 15, 206-213. https://doi.org/10.1002/fee.1484

Macreadie, P. I., Ollivier, Q. R., Kelleway, J. J., Serrano, O., Carnell, P. E., Ewers Lewis, C. J., Atwood, T. B., Sanderman, J., Baldock, J., Connolly, R. M., Duarte, C. M., Lavery, P. S., Steven, A., \& Lovelock, C. E. (2017). Carbon sequestration by Australian tidal marshes. Scientific Reports, 7, 44071. https://doi.org/10.1038/srep44071

Marwick, T. R., Tamooh, F., Teodoru, C. R., Borges, A. V., Darchambeau, F., \& Bouillon, S. (2015). The age of river-transported carbon: A global perspective. Global Biogeochemical Cycles, 29, 122-137. https://doi. org/10.1002/2014GB004911

Mcleod, E., Chmura, G. L., Bouillon, S., Salm, R., Björk, M., Duarte, C. M., \& Silliman, B. R. (2011). A blueprint for blue carbon: Toward an improved understanding of the role of vegetated coastal habitats in sequestering $\mathrm{CO}_{2}$. Frontiers in Ecology and the Environment, 9, 552-560. https://doi.org/10.1890/110004 
Meng, W., Feagin, R. A., Hu, B., He, M., \& Li, H. (2019). The spatial distribution of blue carbon in the coastal wetlands of China. Estuarine, Coastal and Shelf Science, 222, 13-20. https://doi.org/10.1016/j. ecss.2019.03.010

Milliman, J. D., \& Farnsworth, K. L. (2013). River discharge to the coastal ocean: A global synthesis. Cambridge University Press.

Miyajima, T., Hori, M., Hamaguchi, M., Shimabukuro, H., Adachi, H., Yamano, H., \& Nakaoka, M. (2015). Geographic variability in organic carbon stock and accumulation rate in sediments of East and Southeast Asian seagrass meadows. Global Biogeochemical Cycles, 29, 397-415. https://doi.org/10.1002/2014GB004979

Mu, X., Liu, X., Yan, B., \& Cui, B. (2015). Classification system of coastal wetlands in China. Wetland Science, 13, 19-26. (in Chinese). https:// doi.org/10.13248/j.cnki.wetlandsci.2015.01.004

Murdiyarso, D., Purbopuspito, J., Kauffman, J. B., Warren, M. W., Sasmito, S. D., Donato, D. C., Manuri, S., Krisnawati, H., Taberima, S., \& Kurnianto, S. (2015). The potential of Indonesian mangrove forests for global climate change mitigation. Nature Climate Change, 5, 1089-1092. https://doi.org/10.1038/NCLIMATE2734

Murray, N. J., Phinn, S. R., DeWitt, M., Ferrari, R., Johnston, R., Lyons, M. B., Clinton, N., Thau, D., \& Fuller, R. A. (2019). The global distribution and trajectory of tidal flats. Nature, 565, 222. https://doi. org/10.1038/s41586-018-0805-8

National Development and Reform Commission of China. (2016). The 13th five-year plan for economic and social development of the People's Republic of China. Retrieved from http://www.xinhuanet. com//politics/2016lh/2016-03/17/c_1118366322.htm

National Forestry Administration \& National Development and Reform Commission of China. (2015). National coastal shelterbelt system construction project planning (2016-2025) (in Chinese). Retrieved from http://www.gov.cn/xinwen/2017-05/16/content_5194348.htm

Neumann, B., Vafeidis, A. T., Zimmermann, J., \& Nicholls, R. J. (2015). Future coastal population growth and exposure to sea-level rise and coastal flooding-a global assessment. PLoS ONE, 10, e0118571. https://doi.org/10.1371/journal.pone.0118571

Niu, Z., Zhang, H., Wang, X., Yao, W., Zhou, D., Zhao, K., Zhao, H., Li, N., Huang, H., Li, C., Yang, J., Liu, C., Liu, S., Wang, L., Li, Z., Yang, Z., Qiao, F., Zheng, Y., Chen, Y., ... Gong, P. (2012). Mapping wetland changes in China between 1978 and 2008. Chinese Science Bulletin, 57, 2813-2823. https://doi.org/10.1007/s11434-012-5093-3

Osland, M. J., Gabler, C. A., Grace, J. B., Day, R. H., McCoy, M. L., McLeod, J. L., From, A. S., Enwright, N. M., Feher, L. C., Stagg, C. L., \& Hartley, S. B. (2018). Climate and plant controls on soil organic matter in coastal wetlands. Global Change Biology, 24, 5361-5379. https://doi. org/10.1111/gcb.14376

Ouyang, X., \& Lee, S. Y. (2014). Updated estimates of carbon accumulation rates in coastal marsh sediments. Biogeosciences, 11, 5057-5071. https://doi.org/10.5194/bg-11-5057-2014

Piao, S., Fang, J., Ciais, P., Peylin, P., Huang, Y., Sitch, S., \& Wang, T. (2009). The carbon balance of terrestrial ecosystems in China. Nature, 458, 1009-1013. https://doi.org/10.1038/nature07944

Qu, Y., Jevrejeva, S., Jackson, L. P., \& Moore, J. C. (2019). Coastal Sea level rise around the China Seas. Global and Planetary Change, 172, 454-463. https://doi.org/10.1016/j.gloplacha.2018.11.005

Röhr, M. E., Holmer, M., Baum, J. K., Björk, M., Boyer, K., Chin, D., \& Deyanova, D. (2018). Blue carbon storage capacity of temperate eelgrass (Zostera marina) meadows. Global Biogeochemical Cycles, 32, 1457-1475. https://doi.org/10.1029/2018GB005941

Rovai, A. S., Twilley, R. R., Castañeda-Moya, E., Riul, P., Cifuentes-Jara, M., Manrow-Villalobos, M., Horta, P. A., Simonassi, J. C., Fonseca, A. L., \& Pagliosa, P. R. (2018). Global controls on carbon storage in mangrove soils. Nature Climate Change, 8, 534-538. https://doi. org/10.1038/s41558-018-0162-5

Sanchez-Cabeza, J. A., \& Ruiz-Fernández, A. C. (2012). ${ }^{210} \mathrm{~Pb}$ sediment radiochronology: An integrated formulation and classification of dating models. Geochimica et Cosmochimica Acta, 82, 183-200. https://doi.org/10.1016/j.gca.2010.12.024

Sanders, C. J., Maher, D. T., Tait, D. R., Williams, D., Holloway, C., Sippo, J. Z., \& Santos, I. R. (2016). Are global mangrove carbon stocks driven by rainfall. Journal of Geophysical Research: Biogeosciences, 121, 2600-2609. https://doi.org/10.1002/2016JG003510

Serrano, O., Lovelock, C. E., Atwood, T. B., Macreadie, P. I., Canto, R., Phinn, S., Arias-Ortiz, A., Bai, L. E., Baldock, J., Bedulli, C., Carnell, P., Connolly, R. M., Donaldson, P., Esteban, A., Ewers Lewis, C. J., Eyre, B. D., Hayes, M. A., Horwitz, P., Hutley, L. B., ... Duarte, C. M. (2019). Australian vegetated coastal ecosystems as global hotspots for climate change mitigation. Nature Communications, 10, 1-10. https:// doi.org/10.1038/s41467-019-12176-8

Stock, B. C., \& Semmens, B. X. (2016). MixSIAR GUI User Manual. Version 3.1. Retrieved from https://github.com/brianstock/MixSIAR/

Wang, G., Guan, D., Peart, M. R., Chen, Y., \& Peng, Y. (2013). Ecosystem carbon stocks of mangrove forest in Yingluo Bay, Guangdong Province of South China. Forest Ecology and Management, 310, 539546. https://doi.org/10.1016/j.foreco.2013.08.045

Wang, W., Liu, H., Li, Y., \& Su, J. (2014). Development and management of land reclamation in China. Ocean \& Coastal Management, 102, 415425. https://doi.org/10.1016/j.ocecoaman.2014.03.009

Wang, W., \& Wang, M. (2007). The mangroves of China. Science Press (in Chinese).

Wang, X., Zhang, H., \& Han, G. (2016). Carbon cycle and "blue carbon" potential in China's coastal zone. Bulletin of Chinese Academy of Sciences, 31, 1218-1225 (in Chinese). https://doi.org/10.16418/ j.issn.1000-3045.2016.10.012

Waycott, M., Duarte, C. M., Carruthers, T. J. B., Orth, R. J., Dennison, W. C., Olyarnik, S., Calladine, A., Fourqurean, J. W., Heck, K. L., Hughes, A. R., Kendrick, G. A., Kenworthy, W. J., Short, F. T., \& Williams, S. L. (2009). Accelerating loss of seagrasses across the globe threatens coastal ecosystems. Proceedings of the National Academy of Sciences of the United States of America, 106, 12377-12381. https://doi. org/10.1073/pnas.0905620106

Wu, Z., Zhao, D., Syvitski, J. P. M., Saito, Y., Zhou, J., \& Wang, M. (2020). Anthropogenic impacts on the decreasing sediment loads of nine major rivers in China, 1954-2015. Science of the Total Environment, 739, 139653. https://doi.org/10.1016/j.scitotenv.2020.139653

Xiao, X., Agusti, S., Pan, Y., Yu, Y., Li, K., Wu, J., \& Duarte, C. M. (2019). Warming amplifies the frequency of harmful algal blooms with eutrophication in Chinese coastal waters. Environmental Science \& Technology, 53, 13031-13041. https://doi.org/10.1021/acs.est.9b03726

Xiong, Y., Liao, B., \& Wang, F. (2018). Mangrove vegetation enhances soil carbon storage primarily through in situ inputs rather than increasing allochthonous sediments. Marine Pollution Bulletin, 131, 378-385. https://doi.org/10.1016/j.marpolbul.2018.04.043

Yang, S., \& Chen, J. (1995). Coastal salt marshes and mangrove swamps in China. Chinese Journal of Oceanology and Limnology, 13, 318-324. https://doi.org/10.1007/BF02889465

Yang, Y., Li, P., Ding, J., Zhao, X., Ma, W., Ji, C., \& Fang, J. (2014). Increased topsoil carbon stock across China's forests. Global Change Biology, 20, 2687-2696. https://doi.org/10.1111/gcb.12536

Zhang, H., Luo, Y., Liu, X., \& Fu, C. (2015). Current researches and prospects on the coastal blue carbon. Scientia Sinica Terrae, 45, 16411648 (in Chinese). https://doi.org/10.1360/zd2015-45-11-1641

Zhao, Y., Wang, M., Hu, S., Zhang, X., Ouyang, Z., Zhang, G., Huang, B., Zhao, S., Wu, J., Xie, D., Zhu, B. O., Yu, D., Pan, X., Xu, S., \& Shi, $X$. (2018). Economics-and policy-driven organic carbon input enhancement dominates soil organic carbon accumulation in Chinese croplands. Proceedings of the National Academy of Sciences of the United States of America, 115, 4045-4050. https://doi.org/10.1073/ pnas. 1700292114

Zheng, F., Qiu, G., Fan, H., \& Zhang, W. (2013). Diversity, distribution and conservation of Chinese seagrass species. Biodiversity Science, 
21, 517-526 (in Chinese). https://doi.org/10.3724/SP.J.1003.2013. 10038

Zhou, C., Mao, Q., Xu, X., Fang, C., Luo, Y., \& Li, B. (2016). Preliminary analysis of $C$ sequestration potential of blue carbon ecosystems on Chinese coastal zone. Scientia Sinica Vitae, 46, 475-486 (in Chinese). https://doi.org/10.1360/N052016-00105

Zhou, Y., Xu, S., Xu, S., Yue, S., Gu, R., Zhang, X., \& Zhang, Z. (2018). New discovery of larger seagrass beds with areas $>0.50 \mathrm{~km}^{2}$ in temperate waters of China: II The largest Zostera marina bed in China discovered in the coastal waters of Tangshan in the Bohai Sea by sonar detection technology. Marine Sciences, 43, 50-55 (in Chinese). https://doi. org/10.11759/hykx20190318003

\section{SUPPORTING INFORMATION}

Additional supporting information may be found online in the Supporting Information section.

How to cite this article: Fu C, Li Y, Zeng L, et al. Stocks and losses of soil organic carbon from Chinese vegetated coastal habitats. Glob. Change Biol.2021;27:202-214. https://doi. org/10.1111/gcb.15348 